\title{
Adaptation and Participatory Evaluation of Shrub Forage Legumes in Highlands of Sud-Kivu, Democratic Republic of the Congo (DRC)
}

\author{
Katunga Musale M. Dieudonnéé,2 \\ ${ }^{1}$ International Center for Tropical Agriculture (CIAT), Bukavu, DRC \\ ${ }^{2}$ Institut National pour l'Etude et la Recherche agronomiques (INERA)-Mulungu, Bukavu, DRC \\ Email:katungamusale@yahoo.fr, stylonya@gmail.com
}

How to cite this paper: Dieudonné, K.M.M. (2020) Adaptation and Participatory Evaluation of Shrub Forage Legumes in Highlands of Sud-Kivu, Democratic Republic of the Congo (DRC). Open Access Library Journal, 7: e6165.

https://doi.org/10.4236/oalib.1106165

Received: February 13, 2020

Accepted: March 21, 2020

Published: March 24, 2020

Copyright $\odot 2020$ by author(s) and Open Access Library Inc.

This work is licensed under the Creative Commons Attribution International License (CC BY 4.0).

http://creativecommons.org/licenses/by/4.0/

\begin{abstract}
Livestock in the highlands of DRC faces several constraints. It strongly decreased due to high rate of mortality, looting during the wars, lack of animal feeding and livestock still reared again under traditional system. However, shrub forage legumes can contribute to mitigate one part of these constraints and play an important role to improve livestock production. The objective of this study is to use for adaptation the improved shrub forage legumes previously tested by the International Center for Tropical Agriculture (CIAT) Colombia in tropical Central Asia and Latin America whose ecological conditions are similar to those in DRC. Fifteen shrub forage legumes were randomly planted. With 3 replications, nine plantations were counted per specie or accession. The cutting period was for eight weeks. The best yield shrubs were in Mulungu L. diversifolia K782, L. diversifolia 22192 and in Nyangezi C. calothyrsus. The choice of the farmers in their participatory evaluation was generally in agreement with the agronomic trial outcomes.
\end{abstract}

\section{Subject Areas}

Agricultural Science

\section{Keywords}

Shrubs Forage Legumes, Farmer's Evaluation, Yield, Highland, DRC

\section{Introduction}

In the eastern highlands of the Democratic Republic of the Congo (DRC), livestock faces several constraints that hinder its harmonious development. It strongly 
decreased following several constraints among which the high death rates, lack of animal feeding, social unrests and livestock looting during the wars [1]. There is also the demographic pressure on natural spaces and the increase of malnutrition rate among the population, up to $15 \%$ of global malnutrition [2]. The production of fodders to feed small animals is not practiced yet; it is only done in some private cattle farms [3]. Yet multipurpose forage production is a major component in animal livestock systems to enhance animal production, to control erosions and protect the environment. Shade trees play an important role within the agroforestry systems by influencing radiation and wind regimes as well as nutrient and hydrological cycling [4]. This study aimed to use for adaptation, combined with farmers' participatory evaluation the improved shrub forage legumes previously tested by the International Center for Tropical Agriculture (CIAT) Colombia in tropical Central Asia and Latin America whose ecological conditions are similar to those in DRC.

\section{Material and Methods}

\subsection{Agronomic Trials}

Table 1 shows the location of the sites.

Nyangezi soils are very acidic with low CEC and K than Mulungu site. Shrubs were installed in both sites in January 2009 in Mulungu and Nyangezi sites; see the characteristics of the experimental sites in Table 1. Fifteen shrub forage legumes were planted randomly opposing of the direction of the slop and distant by $1.5 \mathrm{~m}$. In the line, they were separated each other by $1 \mathrm{~m}$. A unit plot for every shrub comprised three plantations with 3 replications. At all, there were nine plants per specie or accession and in addition a line of Callianda calothyrsus made a contour of all the trial. The regulation cutting done in January 2010 was made at $50 \mathrm{~cm}$ of height for Desmodium velutinum and Flemingia macrophylla and at $100 \mathrm{~cm}$ for Calliandra calothyrsus, Leucaena diversifolia, Cratylia argentea and Leucaena leucocephala. The harvest cuttings were made every eight weeks; the first one took place in March 2010 and finished on February 2011. Before every cut, height of plantations was measured, leaves and stems of each specie or accessions were weighed with an electronical weighing balance SF-400 $(1 \mathrm{~g} \pm 10 \mathrm{~kg})$. For each specie and accession, a homogeneous sub-sample of $300 \mathrm{~g}$ of leaves and stems were taken at every harvest and dried during three months until the constant weight in a hangar at Kalambo CIAT office that reached $40^{\circ} \mathrm{C}$ to $45^{\circ} \mathrm{C}$ during the bright time. Nutritional quality (Dry mater $=\mathrm{DM}$, Organic

Table 1. Location of the experimental sites and some characteristics.

\begin{tabular}{cccccccc}
\hline \multicolumn{3}{c}{ Location of the site } & \multicolumn{4}{c}{ Soil fertility } \\
\hline Site & Latitude & Longitude & Elevation (m asl) & $\mathrm{pH}$ & $\mathrm{K}$ & $\mathrm{P}(\mathrm{O})$ & CEC $^{*}$ \\
\hline Mulungu & $2.19^{\circ} \mathrm{S}$ & $28.47^{\circ} \mathrm{E}$ & 1700 & 5.15 & 0.36 & 3 & 20 \\
Nyangezi & $2.88^{\circ} \mathrm{S}$ & $27.03^{\circ} \mathrm{E}$ & 1580 & 3.94 & 0.18 & 3 & 3 \\
\hline
\end{tabular}

${ }^{\star}$ Cationic exchange capacity. 
matter $=\mathrm{OM}$, crude proteins $=\mathrm{CP}$, neutral detergent fiber $=$ NDF and True in vitro Organic Mater Digestibility = TIVOMD) of only leaf samples was analyzed by near infrared reflectance spectroscopy (NIRS) at the International Livestock Research Institute (ILRI), Addis-Ababa, Ethiopia.

$$
\begin{aligned}
& \text { Mean fresh leaf and stem yield }(\text { MFLSY) in g/plant } \\
& =\frac{\text { Fresh weight }(\mathrm{g}) \times \text { dry matter }(\%)}{\text { Number of plants } \times 100[5]}
\end{aligned}
$$

Impacts of diseases and insects' damages were observed according to the [5] scale from 1 to 5 .

\subsection{Farmers Participatory Evaluation}

Choices of forages in farmer's participatory sessions were evaluated at both sites with the people involved in the seasonal trials. They were organized in a development association. To proceed to choice, farmers were subdivided into 2 groups according to the gender during the rain and dry seasons. A team comprised 5 women and another 5 men. A participating farmer had to select the three best plots in terms of crop performance by dropping a white paper in those plots chosen. Data were presented as ranks of preference by location. After the choice of forages, the two teams met to discuss for a consensus between genders [6].

\subsection{Data Analysis}

Data were statistically computed for descriptive statistics and Analysis of variance (ANOVA) using Tukey test in Genstat, Statview version 5.0. Cluster analysis was calculated by Past version 2.15. The agronomic and farmer's participatory evaluation data were computed. Means and Standard Error of Mean (SEM) are presented.

\section{Results}

\section{Agronomic Evaluation}

\section{Nutritive Values}

Table 2 shows the nutritive values of shrub forage legumes.

$\mathrm{CP}$ in Mulungu are very good with a range of $19.0 \%-28.2 \%$ while in Nyangezi it is $17.9 \%-27 \%$. ADF at both sites are very high for D. velutinum (13218, 334443, 23982 and 23996) and F. macrophylla 17403.

\section{Diseases and Insect's Attacks}

Table 3 shows the diseases and insects ranks of the shrubs.

Fodders without diseases and pests' damages in Mulungu and in Nyangezi were C. calothyrsus, all accessions of $L$. diversifolia (17503, 22192, 15551, K780, K782) and L. leucocephala 17263 except for Nyangezi where L. diversifolia 17503 suffered from diseases. 
Table 2. Chemical analysis of forges in the sites.

\begin{tabular}{|c|c|c|c|c|c|c|c|c|c|c|}
\hline \multirow{2}{*}{ Shrub forage legumes } & \multicolumn{5}{|c|}{ Mulungu } & \multicolumn{5}{|c|}{ Nyangezi } \\
\hline & $\mathrm{DM}$ & $\mathrm{OM}$ & $\mathrm{CP}$ & $\mathrm{ADF}$ & TIVOMD & $\mathrm{DM}$ & $\mathrm{OM}$ & $\mathrm{CP}$ & $\mathrm{ADF}$ & TIVMOD \\
\hline C. argentea 18516 & 25.6 & 90.2 & 24.1 & 29.9 & 58.2 & 23.1 & 91.6 & 21.6 & 30.5 & 60.5 \\
\hline C. calothyrsus & 21.4 & 94.3 & 27.2 & 29.3 & 55.0 & 30.7 & 96.4 & 21.2 & 28.2 & 61.7 \\
\hline D. velutinum 13218 & 22.9 & 89.7 & 22.6 & 36.4 & 52.6 & 27.6 & 91.7 & 20.8 & 33.6 & 60.7 \\
\hline D. velutinum 33443 & 27.3 & 89.7 & 21.9 & 37.8 & 52.5 & 38.4 & 92.2 & 18.9 & 34.7 & 61.1 \\
\hline D. velutinum 23982 & 25.4 & 89.7 & 22.1 & 34.7 & 52.9 & 30.8 & 91.5 & 19.3 & 34.2 & 59.6 \\
\hline D. velutinum 23996 & 28.3 & 89.6 & 19.0 & 38.9 & 50.5 & 31.1 & 91.3 & 18.5 & 35.1 & 58.9 \\
\hline F. macrophylla 17403 & 22.5 & 95.2 & 23.5 & 33.9 & 50.4 & 29.5 & 96.8 & 17.9 & 32.7 & 52.8 \\
\hline F. macrophylla 18438 & 31.6 & 93.8 & 26.0 & 24.5 & 58.5 & 28.0 & 96.6 & 19.7 & 30.9 & 55.1 \\
\hline F. macrophylla 20618 & 24.5 & 95.3 & 22.4 & 32.6 & 50.6 & 27.4 & 96.5 & 18.6 & 31.3 & 55.6 \\
\hline L. diversifolia 17503 & 25.4 & 92.7 & 29.7 & 22.9 & 60.3 & 32.1 & 95.0 & 22.4 & 26.8 & 58.7 \\
\hline L. diversifolia 22192 & 24.6 & 93.3 & 28.2 & 26.1 & 57.8 & 32.3 & 89.7 & 27.0 & 30 & 55.1 \\
\hline L. diversifolia K780 & 25.7 & 91.1 & 25.9 & 25.7 & 60.7 & 31.1 & 94.4 & 24.2 & 25.8 & 60.7 \\
\hline L. diversifolia K782 & 24.2 & 93.6 & 28.0 & 26.1 & 59.6 & 33.8 & 96.1 & 22.8 & 26.1 & 60.5 \\
\hline L. leucocephala 17263 & 24.0 & 91.1 & 25.9 & 25.7 & 60.6 & 28.0 & 96.2 & 23.9 & 27.2 & 61.1 \\
\hline L. diversifolia 15551 & 24.4 & 93.4 & 27.9 & 28.1 & 54.8 & 32.5 & 96.0 & 21.6 & 29.2 & 57.9 \\
\hline
\end{tabular}

Table 3. Ranks of diseases and insects attack of the shrub forage legumes.

\begin{tabular}{ccccc}
\hline \multirow{2}{*}{ Shrubs forage legumes } & \multicolumn{2}{c}{ Mulungu } & \multicolumn{2}{c}{ Nyangezi } \\
\cline { 2 - 5 } & Diseaes & Insects & Diseases & Insects \\
\hline C. argentea 18516 & 2 & 2 & 2 & 2 \\
C. calothyrsus & 1 & 1 & 1 & 1 \\
D. velutinum 33443 & 2 & 2 & 2 & 2 \\
D. velutinum 23982 & 2 & 2 & 2 & 2 \\
D. velutinum 23996 & 2 & 2 & 2 & 2 \\
D. velutinum 13218 & 2 & 2 & 2 & 2 \\
F. macrophylla 17403 & 2 & 2 & 2 & 2 \\
F. macrophylla 18438 & 2 & 2 & 2 & 2 \\
F. macropylla 20618 & 2 & 2 & 2 & 1 \\
L. diversifolia 17503 & 1 & 1 & 2 & 1 \\
L. diversifolia 22192 & 1 & 1 & 1 & 1 \\
L. diversifolia 15551 & 1 & 1 & 1 & 1 \\
L. diversifolia K780 & 1 & 1 & 1 & 1 \\
L. diversifolia K782 & 1 & & & 2 \\
L. leucocephala 17263 & 1 & 1 & 2 & 2 \\
\hline
\end{tabular}


Yield Biomass of Shrubs

Table 4 shows the height and vigor of shrubs.

Similar letters in Table 4 imply no significant difference according to Tukey grouping. There is a highly significant difference between the means of the height of shrubs $(\mathrm{P}<0.001)$ at both sites.

The tallest forages at both sites was $C$. calothyrsus. The best vigor of shrub was observed in Mulungu on L. diversifolia (17503, 15551, 22192, K780, K782), L. leucocephala, C. calothyrsus and in Nyangezi on C. calothyrsus.

Table 5 shows the yield of shrub forage legumes.

Similar letters in Table 5 imply no significant difference according to Tukey grouping. There was a highly significant difference between the means of fresh leaves weight and stems yield at both sites $(\mathrm{P}<0.001)$. The best yield forages were L. diversifolia K782, L. diversifolia 22192 in Mulungu and C. calothyrsus in Nyangezi. At both sites level, $C$. calothyrsus is the best shrub in terms of yield. Figure 1 shows the cluster of shrubs.

Figure 1 shows that the first cluster included $C$. calothyrsus and five accessions of $L$. diversifolia (17503, 22192, 15551, K780, K782), the second cluster included the other shrubs.

Participatory Evaluation by Farmers

Table 6 shows the choice of forages by farmers in Mulungu and Nyangezi.

Table 4. Height of shrub forage legumes (means and SEM).

\begin{tabular}{ccccc}
\hline \multirow{2}{*}{ Shrub forage legumes } & \multicolumn{2}{c}{ Height $(\mathrm{cm})$} & \multicolumn{2}{c}{ Vigor } \\
\cline { 2 - 5 } & Mulungu & Nyangezi & Mulungu & Nyangezi \\
\hline C. argentea 18516 & $152.1 \pm 6.2^{\mathrm{cd}}$ & $123.6 \pm 6.1^{\mathrm{bc}}$ & 4 & 3 \\
C. calothyrsus & $187.7 \pm 5.0^{\mathrm{a}}$ & $164.6 \pm 8.6^{\mathrm{a}}$ & 5 & 5 \\
D. velutinum 33443 & $80.1 \pm 4.4^{\mathrm{de}}$ & $75.1 \pm 6.5^{\mathrm{de}}$ & 3 & 4 \\
D. velutinum 23982 & $70.6 \pm 5.4^{\mathrm{de}}$ & $71.0 \pm 5.2^{\mathrm{de}}$ & 3 & 4 \\
D. velutinum 23996 & $81.6 \pm 8.5^{\mathrm{d}}$ & $73.5 \pm 4.9^{\mathrm{de}}$ & 4 & 3 \\
D. velutinum 13218 & $60.3 \pm 2.6^{\mathrm{e}}$ & $68.1 \pm 4.4^{\mathrm{de}}$ & 3 & 3 \\
F. macrophylla 17403 & $71.0 \pm 3.1^{\mathrm{de}}$ & $91.3 \pm 8.3^{\mathrm{cd}}$ & 4 & 4 \\
F. macrophylla 18438 & $46.2 \pm 2 \cdot 8^{\mathrm{ef}}$ & $71.9 \pm 8.7^{\mathrm{de}}$ & 2 & 2 \\
F. macropylla 20618 & $75.4 \pm 5.0^{\mathrm{de}}$ & $76.6 \pm 4.8^{\mathrm{d}}$ & 3 & 4 \\
L. diversifolia 17503 & $170.9 \pm 4.9^{\mathrm{bc}}$ & $120.1 \pm 6.1^{\mathrm{bc}}$ & 5 & 3 \\
L. diversifolia 22192 & $166.3 \pm 4.2^{\mathrm{cd}}$ & $133.1 \pm 8.9^{\mathrm{b}}$ & 5 & 3 \\
L. diversifolia 15551 & $166.8 \pm 6.2^{\mathrm{c}}$ & $125.1 \pm 7.2^{\mathrm{bc}}$ & 5 & 3 \\
L. diversifolia K780 & $177.0 \pm 6.9^{\mathrm{b}}$ & $130.2 \pm 9.8^{\mathrm{bc}}$ & 5 & 3 \\
L. diversifolia K782 & $170.7 \pm 8.2^{\mathrm{bc}}$ & $126.7 \pm 9.1^{\mathrm{bc}}$ & 5 & 3 \\
L. leucocephala 17263 & $173.9 \pm 7.4^{\mathrm{bc}}$ & $104.6 \pm 2.7^{\mathrm{c}}$ & 5 & - \\
\hline Lsd (P $<0.05)$ & 18.4 & 21.9 & 5 & 3 \\
\hline
\end{tabular}


Table 5. MFLSY of the shrub forage legumes (g/plant and SEM).

\begin{tabular}{cccc}
\hline Shrub forage legumes & Mulungu & Nyangezi & Means at both sites \\
\hline C. argentea CIAT 18516 & $107.2 \pm 10.4^{\mathrm{d}}$ & $18.6 \pm 3.3^{\mathrm{cd}}$ & $62.9 \pm 9.2^{\mathrm{de}}$ \\
C. calothyrsus & $405.4 \pm 38.2^{\mathrm{b}}$ & $339.2 \pm 51.6^{\mathrm{a}}$ & $372.3 \pm 32.1^{\mathrm{a}}$ \\
D. velutinum CIAT 33443 & $56.8 \pm 2.5^{\mathrm{de}}$ & $72.9 \pm 12.3^{\mathrm{cd}}$ & $64.8 \pm 7.6^{\mathrm{de}}$ \\
D. velutinum CIAT 23982 & $60.3 \pm 18.7^{\mathrm{de}}$ & $81.3 \pm 28.6^{\mathrm{c}}$ & $72.3 \pm 18.2^{\mathrm{de}}$ \\
D. velutinum CIAT 23996 & $67.1 \pm 12.5^{\mathrm{de}}$ & $71.9 \pm 14.8^{\mathrm{cd}}$ & $69.5 \pm 9.5^{\mathrm{de}}$ \\
D. velutinum CIAT 13218 & $7.6 \pm 10.5^{\mathrm{ef}}$ & $47.3 \pm 18.7^{\mathrm{cd}}$ & $29.2 \pm 10.6^{\mathrm{de}}$ \\
F. macrophylla CIAT 17403 & $196.6 \pm 38.8^{\mathrm{cd}}$ & $124.4 \pm 27.4^{\mathrm{bc}}$ & $161.6 \pm 24.4^{\mathrm{c}}$ \\
F. macrophylla CIAT 18438 & $10.8 \pm 4.2^{\mathrm{e}}$ & $12.8 \pm 5.4^{\mathrm{d}}$ & $11.9 \pm 3.5^{\mathrm{de}}$ \\
F. macropylla CIAT 20618 & $155.3 \pm 22.8^{\mathrm{cd}}$ & $160.4 \pm 32.2^{\mathrm{b}}$ & $157.9 \pm 19.4^{\mathrm{cd}}$ \\
L. diversifolia CIAT 17503 & $399.6 \pm 30.1^{\mathrm{bc}}$ & $23.1 \pm 12.5^{\mathrm{cd}}$ & $211.4 \pm 31.5^{\mathrm{bc}}$ \\
L. diversifolia CIAT 22192 & $447.7 \pm 33.8^{\mathrm{ab}}$ & $98.4 \pm 6.3^{\mathrm{bc}}$ & $273.0 \pm 36.5^{\mathrm{bc}}$ \\
L. diversifolia ILRI 15551 & $366.7 \pm 34.1^{\mathrm{bc}}$ & $48.7 \pm 21.4^{\mathrm{cd}}$ & $207.7 \pm 35.6^{\mathrm{bc}}$ \\
L. diversifolia K780 & $354.8 \pm 39.7^{\mathrm{bc}}$ & $72.8 \pm 20.7^{\mathrm{cd}}$ & $213.8 \pm 32.5^{\mathrm{bc}}$ \\
L. diversifolia K782 & $511.2 \pm 50.5^{\mathrm{a}}$ & $57.2 \pm 15.9^{\mathrm{cd}}$ & $284.2 \pm 46.4^{\mathrm{b}}$ \\
L. leucocephala CIAT 17263 & $200.0 \pm 21.9^{\mathrm{c}}$ & $7.8 \pm 2.1^{\mathrm{de}}$ & $103.9 \pm 19.5^{\mathrm{d}}$ \\
Lsd (P $<0.05)$ & 93.9 & 67.8 & 80.7 \\
\hline
\end{tabular}

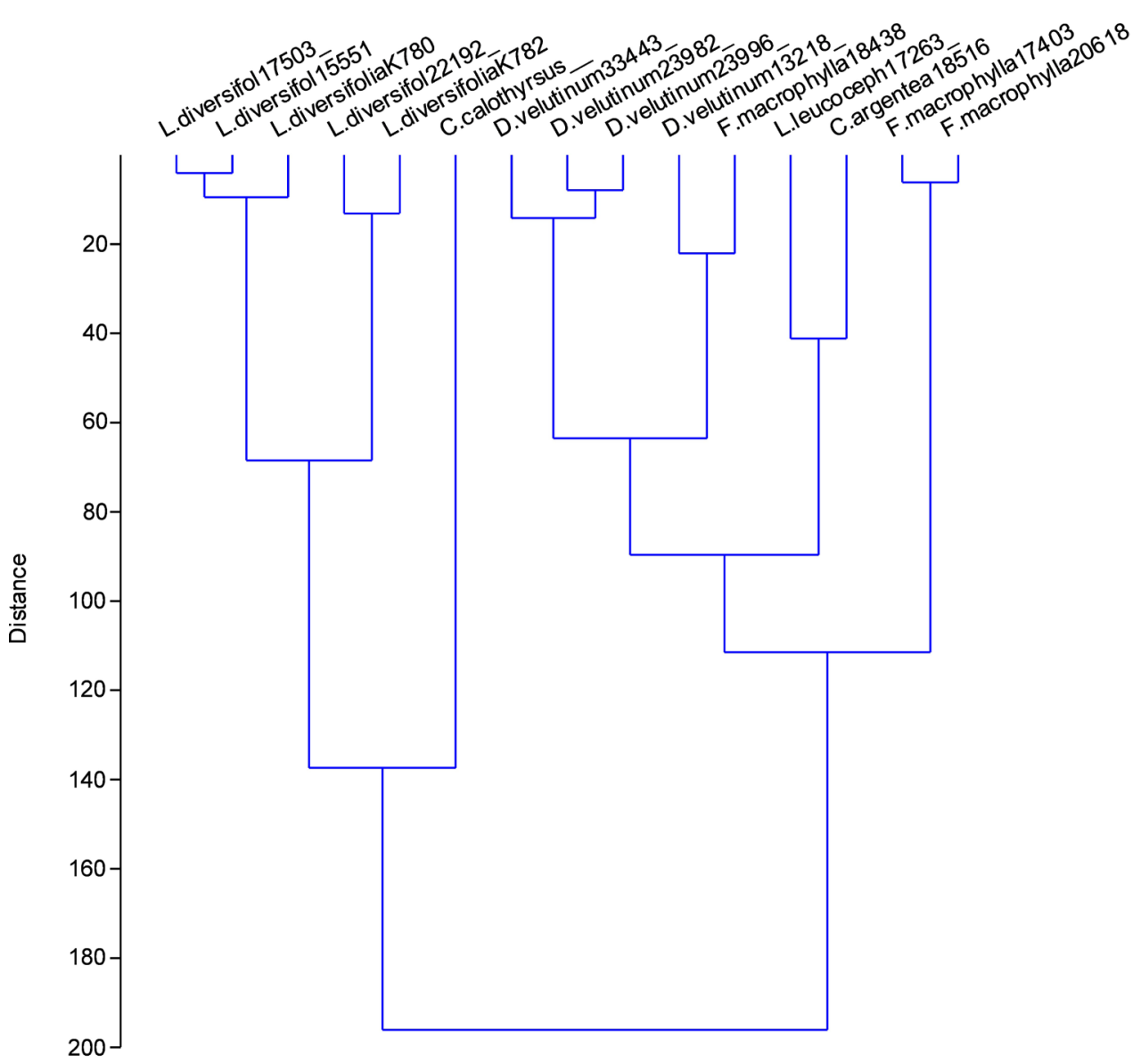

Figure 1. Cluster based on variables MFLSY, CP and height of shrubs legumes at both sites. 
Table 6. Choice by farmers.

\begin{tabular}{|c|c|c|c|c|}
\hline \multirow{2}{*}{ Shrub forage legumes } & \multicolumn{2}{|c|}{ Rainy season } & \multicolumn{2}{|c|}{ Dry season } \\
\hline & Mulungu & Nyangezi & Mulungu & Nyangezi \\
\hline C. calothyrsus & $1^{\mathrm{st}}$ & $1^{\mathrm{st}}$ & $1^{\mathrm{st}}$ & $2^{\text {nd }}$ \\
\hline C. argentea & 0 & 0 & $2^{\text {nd }}$ & 0 \\
\hline D. velutinum 13218 & 0 & $5^{\text {th }}$ & 0 & 0 \\
\hline D. velutinum 23982 & 0 & 0 & 0 & $3^{\text {rd }}$ \\
\hline D. velutinum 23996 & 0 & 0 & 0 & $5^{\text {th }}$ \\
\hline F. macrophylla 17403 & 0 & 0 & 0 & 0 \\
\hline F. macrophylla 18438 & 0 & 0 & 0 & $4^{\text {th }}$ \\
\hline F. macrophylla 20618 & 0 & 0 & 0 & $1^{\text {st }}$ \\
\hline L. diversifolia 15551 & $3^{\text {rd }}$ & 0 & $5^{\text {th }}$ & 0 \\
\hline L. diversifolia 22192 & $2^{\text {nd }}$ & 0 & 0 & 0 \\
\hline L. diversifolia K780 & $6^{\text {th }}$ & $4^{\text {th }}$ & 0 & 0 \\
\hline L. diversifolia K782 & $4^{\text {th }}$ & $2^{\text {nd }}$ & $3^{\text {rd }}$ & 0 \\
\hline L. leucocephala & $5^{\text {th }}$ & $3^{\text {rd }}$ & $4^{\text {th }}$ & 0 \\
\hline
\end{tabular}

During the rainy season, $C$. calothyrsus was the most chosen at the first step in both the sites following by $L$. diversifolia 22192 in Mulungu and L. diversifolia K782 in Nyangezi. In dry season first choice was made for C. calothyrsus in Mulungu and F. macrophylla 20,618 in Nyangezi followed by C. calothyrsus in Nyangezi and $C$. argentea in Mulungu.

\section{Discussion and Conclusion}

The impact of diseases and insects' attacks was lower in Mulungu and Nyangezi than in Colombia [7]. The healthiest shrub forage legumes at both sites were C. calothyrsus, $L$. diversifolia 22192, L. diversifolia 15551, L. diversifolia K780, L. diversifolia K782 and L. leucocephala. In Mulungu, the height of C. calothyrsus was $187.7 \mathrm{~cm}$ a mean after two weeks and is tallest than $170 \mathrm{~cm}$ observed in Rwanda after six months [8]. At both the sites, C. calothyrsus was the higher shrub. The best yield and vigorous shrubs in Mulungu were obtained on L. diversifolia (K782 and 22192). Their CP were in the same range of $25 \%$ to $32 \%$ and the TIVMOD between $56 \%$ to $61 \%$ [9]. Digestibility in vitro observed on C. calothyrsus is better than the range of $24.0 \%$ to $47 \%$ observed by [9]. The best yield production at both two sites is given by $C$. calothyrsus. It is from Central America and Mexico [9]. This shrub adjusted well without depending much on the level of soil fertility and can be considered as an option in the livestock production systems in infertile soils like F. macrophylla [10]. According to the farmers, their choices correspond to the one retained during the agronomic trials as observed [11] on cassava-legumes intercropping system in Sud-Kivu DRC. 


\section{Acknowledgements}

Research was funded by the German federal ministry for Economic Cooperation and Development (BMZ) through the project "Project More chicken and pork in the pot, and money in the pocket Improving fodders for monogastric animals with low-income farmers Research project funded by BMZ Germany for Columbia, Nicaragua and DRC" executed by CIAT with the collaboration of INERA Mulungu, DRC. Special thanks are addressed to researcher's seniors Dr. Peter M. and Prof. Maass B. L. for their scientific support and all other people who helped us to achieve these researches.

\section{Conflicts of Interest}

The author declares no conflicts of interest regarding the publication of this paper.

\section{References}

[1] Cox, T.P. (2011) Farming in the Battlefield: The Meanings of War, Cattle, and Soil in South Kivu, Democratic Republic of the Congo. Disasters, 36, 233-248. https://doi.org/10.1111/j.1467-7717.2011.01257.x

[2] MINAGRIDRAL (2013) Ministère de l'agriculture et du développement rural, plan national d'investissement agricole PNIA 2013-2020 Ministère Agriculture et développement rural R. D. C, 2013.

[3] Katunga, M.M.D. (2014) Evaluation des légumineuses fourragères dans un système d'élevage Editions universitaires européennes (08-07-2014). PhD Thesis, University of Lubumbashi, D.R.C. http://www.editions-ue.com/

[4] Tiralla, N., Panferov, O. and Knol, A. (2011) Allometric Relationship of Frequently Used Shade Tree Species in Cacao Agroforestery Systems in Sulawesi, Indonesia Tropentag. Development on Margin Books of Abstracts University of Bonn, Bonn, 242. http://www.tropentag.de

[5] Toledo, J.M. (1987) Manual para la Evaluación Agronómica Red Internacional de Evaluación de Pastos Tropicales. CIAT, Cali, Colombia 1982, 170 p.

[6] Stür, W.W., Horne, P.M., Gabunada Jr., F.A., Phengsavanh, P. and Kerridge, P.C. (2002) Forage Options for Smallholder Crop-Animal Systems in Southeast Asia: Working with Farmers to Find Solutions. Agricultural Systems, 71, 75-98. https://doi.org/10.1016/S0308-521X(01)00037-3

[7] Andersson, M.S., Schultze-Kraft, R., Peters, M., Hincapie, B. and Lascano, C.E. (2006) Morphological, Agronomic and Fodder Quality Diversity of the Flemingia macrophylla 2006: World Collection. Crops Research, 96, 387-406.

http://www.Sciencedirect.com https://doi.org/10.1016/j.fcr.2005.09.002

[8] Egli, A. (1988) Les arbres et arbustes fourragers au Rwanda Programme d'agroforesterie de l'ISAR 1982-1986 Butare Note Technique No. 2. ISAR, Rwanda, 67 p.

[9] Cook, B., Pengelly, B., Brown, S., Donnelly, J., Eagles, D., Franco, A., Hanson, J., Mullen, B., Partridge, I., Michael, P. and Schultze-Kraft, R. (2005) CIAT, 2005: Tropical Fodders Index Fodders. http://www.tropicalfodders.info

[10] Andersson, M.S., Lascano, C.E., Schultze-Kraft, R. and Peters, M. (2006) Fodder 
Quality and Tanin Concentration and Composition of a Collection of the Tropical Shrub Legume Flemingia macrophylla. Journal of the Science of Food and Agriculture, 86, 1023-1031. https://doi.org/10.1002/jsfa.2433

[11] Pypers, P., Sanginga, J.M., Kasereka, B., Walangululu, M. and Van Lauwe, B. (2010) Increasing Productivity through Integrated Soil Fertility Management in Cassava-Legumes Intercropping System in the Highlands of Sud-Kivu, DR, Congo. Field Crops Research, 120, 76-85. http://www.elseivier.com/locate/fcr https://doi.org/10.1016/j.fcr.2010.09.004 